\title{
PERFORMANCE AND CARCASS CHARACTERISTICS OF FINISHING PIGS FED RAW OR EXTRUDED FULL-FAT SOYA BEANS RATIONS IN HUMID LOWLAND TROPICS
}

\author{
H.A. FASHINA-BOMBATA AND 0.0. TEWE' \\ Facalyy of Science, Lagas State University, Ojo P.M.B. 1087, Apapa, Nigeria \\ Rexived 17 October, 1992; Revised MS Received 21 March 1994; Acoepted 26 Januany 1995
}

\begin{abstract}
Sixteca Ladrace x Large White crossbred pigs averating $56 \mathrm{~kg}$ body weight were used in a study to lwestigate the effects of feeding raw full-fat soya bean (RSB) rations on the performance of pigs in humid lowland tropics. Raw foll-fint soya bean was used to replace extruded full-fat soyabean at 33,67 and $109 \%$ in finishinty swine diets having $16 \%$ C.P. and 2800 kcal/kgME and fed $a d$ lib. ADG was reduced by the addition of RSB to the diets $(P>0.05)$. However, FE was improved $(P>0.05)$ when 67 and $100 \%$ RSB were added to the diets. RSB significantiy $(P<0.05)$ affected backfat deposition and percent lean cut of the carcass. 'Other carcass traits were not affected.
\end{abstract}

Keywords Pig, finishers, Full-Fat Soyabean,

\section{INTRODUCTION}

The cost of processing soyabean has further increased the price of extruded full-fat soyabeans, thereby limiting its use in rations for finishing pigs. The use of raw soyabeans in rations for finishing pigs will reduce the problems of processing soyabeans encountered by small scale farmers. This will be advantageous to swine producers that might wish to plant soyabeans to supplement feeding and increase production of their livestock. The possibilities of using raw soyabeans in rations for growing pigs have been reported by many cuthors (Crenshaw and Danielson, 1985; Daniel, 1985; Pontiff et al, 1987). Hanke, et al, (1972) indicated that swine cannot utilize raw soyabeans as efficiently as soyabean meal. However, Crenshaw and Danielson (1985) reported that gestating gilts fed with diets

1. Department of Animal Science, University of Ibadan, Ibadan.

Nigerlan Journal of Animal Production 22(1) 1995 having raw soyabeans as the sole supplemental protein source gained weight and were reproductively as efficient as gilts fed soyabean meal. Responses of finishing pigs have been variable as Combs and Wallance (1969) found raw soyabeans to be comparable to processed soyabean meal for 16 - week old pigs. In contrast, Pentiff et al, (1987) found that dietary level as low as $6.4 \%$ of raw soyabeans reduced performance. It would seem therefore that pigs are able to tolerate some level of raw soyabeans in their diets (Pontiff et al, 1987). It is against this background that this study was conducted to determine a level soyabeans would not adversely affect pig performance and carcass quality.

\section{MATERIALS AND METHOD}

\section{Animals and Experimental Design and Diets}

16 crossbred Landrace X Large White pigs averaging $55.0 \mathrm{~kg}$ body weight were used. They were housed individually in total confinement on concrete floors. $A$ completely randomized design was used in which pigs were allocated to treatment on the basis of weight. The composition of diets used in this study is presented in Table 1.

\section{Chemical and Statistical Analyses}

Proximate analyses of the test ingredients were carried out using the methods of AOAC (1984). Trypsin inhibitor activity (TLA) and Urease activity (UA) were determined by the methods of AACC (1969).

All data were subjected to analysis of variance (ANOVA) as described by Steel and Torrie (1980) and significant difference between means assessed by applying Duncan's multiple range test (Duncan, 1955). 


\section{Carcass Measurements}

Measurement of carcass traits was carried fout on the hot carcasses immediately after slaughter and removal of hair and viscera and after chilling the left half of the carcasses at $0^{0} \mathrm{c}$ in the cold room for 24 hours.

\section{RESULTS}

The gross composition of diets used in this study are presented in Tables 1 and 2 whilc Table 3 shows the performance data of the pigs. Performance was not affected by dietary treatments. Raw Soyabeans inclusion in diet $2(6.6 \%)$ reduced average daily feed intake (ADFI). Subsequent increase in the level of raw materials (RSB) improved ADFI but not significantly. Average daily gain (ADG) was not significantly influenced by the level of RSB in the diets. Raw Soyabeans inclusion in the diets reduced gains and this was pronounced at $6.6 \%$ level of inclusion. However, subsequent increase in the level of RSB (13.4 \& $23 \%$ ) showed slight improvement but not to the level of gains attained by the control group. Feed efficiency (FE) was not significantly affected by the level of RSB in the diets. Diets 1 and 4 were similar for FE while diets 3 and 4 showed some improvements. $23 \%$ RSB diet was more efficiently utilised $(P>0.05)$ than any other level of RSB.

The results of carcass characteristics are presented in Table 4. There were no significant difference between diets due to the use of RSB except for \% fats cuts, backfat thickness and \% lean cuts. Backfat thickness was significantly decreased $(\mathrm{P}<0.05)$ by $33 \%$ RSB diet and was significantly increased $(\mathrm{P}<0.05)$ by $13.4 \%$ RSB diet. Levels of 0 and $23 \%$ RSB diets were similar but significantly different $(P<0.05)$ from 6.6 and $13.4 \%$ RSB diets. Percent lean cuts was significantly improved in diet 2 having 6.6\% RSB. Diet 4 had the least $(\mathrm{P}<0.05) \%$ lean yield. Warm dressing percentage and estimated loin eye area were not significantly affected by the diets. The results showed that diets 1 and 4 promoted higher yields $(P>0.05)$ than diets 2 and 3. The same trend was noted for carcass length, (Table 4).
Calculated lysine and methionine levels decreased as the level of raw soyabeans increased in the diets (Table 1). Raw soyabeans used in the study was analysed for trypsin inhibitor aclivily (TIA) and Urease activity (UA) The results of TIA and UA are presented on Table 2.

\section{DISCUSSION:}

This study was aimed at determining the level of raw soyabeans that could be utilized by finishing pigs. This level of raw soyabean, it was hoped, would not compromise performance and productivity of pigs while maintaining healthy physiological status. Results of the study showed that the use of raw soyabean would depress feed intake at all levels of inclusion. This report is similar to the findings of Cooks and Frayley (1987) who observed that there was a general depression in feed intake by pigs fed raw high trypsin soyabean. Raw soyabcan inclusion in the diets reduced gains. This was pronounced at $6.6 \%$ level of inclusion. However, there were improvements at the subsequent levels (13.4 and $23 \%$ ). Feed efficiency was improved by 13.4 and $23 \%$ RSB dicts. Pantiff et al., (1987) showed that $33 \%$ RSB replacement of protcin supplement in diet reduced gain when compared with the control diet but that there was no further reduction in gain from $67 \%$ RSB replacement of protein supplement in the diets. The present study is peculiar in that only $6.6 \%$ or $33 \%$ RSB replacement of full fat soyabean maal showed depressed gain and feed efficiency. This agrees with the findings of Pontilf et al., (1987) but unlike previous studies (Cooks and Froley, 1987; Hank et al, 1972; Yen et al., 1974; Vandergrift et al., 1983 Crenshaw and DanicIson, 1985), the study strongly suggests the use of RSB as the sole supplemental protein for finishing pigs.

The results of carcass characteristics did not show significant difference due to the dietary treatments. However, percent lean cut was significantly higher $(\mathrm{P}<0.05)$ at $6.6 \% \mathrm{RS}$ $B$ inclusion. Estimated loin eye area (LEA) was reduced by the addition of RSB to the diets but not significantly $(P>0.05)$. The 
TABLE 1: COMPOSITION OF DIETS BASED ON RAW (RSB) OR EXTRUDED FULL FAT SOYA BEAN (EFFSB)

\begin{tabular}{|c|c|c|c|c|}
\hline \multirow[t]{2}{*}{ INGREDIENTS } & \multicolumn{4}{|c|}{ DIETS } \\
\hline & 1 & 2 & 3 & 4 \\
\hline Corn Meal & 45.00 & 44.00 & 43.00 & 44.00 \\
\hline Corn Offal & 30.00 & 30.00 & 30.00 & 30.00 \\
\hline EFFSB & 20.00 & 14.40 & 8.60 & - \\
\hline RSB & - & 6.60 & 13.40 & 23.00 \\
\hline Bone Meal & 2.00 & 2.00 & 2.00 & 2.00 \\
\hline Oyster Shell & 1.50 & 1.50 & 1.50 & 1.50 \\
\hline Salt & 0.50 & 0.50 & 0.50 & 0.50 \\
\hline Premix ${ }^{a}$ & 1.00 . & 1.00 & 1.00 & 1.00 \\
\hline Total & 100.00 & 100.00 & 100.00 & 100.00 \\
\hline \multicolumn{5}{|l|}{ Calculated analysis } \\
\hline Crude Protein (\%) & 16.00 & 16.20 & 16.20 & 16.20 \\
\hline $\mathrm{ME}(\mathrm{kcal} / \mathrm{g})$ & 2.83 & 2.81 & 22.78 & 2.78 \\
\hline Lysine $(\mathrm{g} / \mathrm{kg})$ & 7.19 & 5.97 & 4.59 & 2.66 \\
\hline Methionine & 2.09 & 1.09 & 1.49 & 1.09 \\
\hline
\end{tabular}

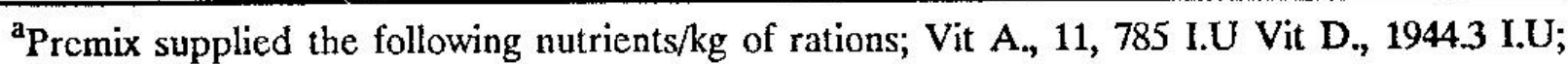
Riboflavin, $5.4 \mathrm{mg}$; pantothenic acid $9.82 \mathrm{mg}$; Nicotinic acid $24.55 \mathrm{mg}$; folic acid $0.98 \mathrm{mg}$; Chloride $4 \times 105 \mathrm{mg}$; Vit E, 4.911.u; Vit K $2.20 \mathrm{mg}$, Vit B $0.01 \mathrm{mg}$; Methionine $245.53 \mathrm{mg}$, Cobalt $1.23 \mathrm{mg}$; iodine $0.98 \mathrm{mg}, \mathrm{C}$ u $9.82 \mathrm{mg} ; \mathrm{Mn} .55 .0 \mathrm{mg} ; \mathrm{Zn} 49.11 \mathrm{mg}$; and Fe. $19.64 \mathrm{mg}$.

TABLE 2: PROXIMATE COMPOSITION AND GROSS ENERGY OF FEED INGREDIENTS

\begin{tabular}{llllllllll}
\hline JATE & $\begin{array}{l}\mathrm{DM} \\
(\%)\end{array}$ & $\begin{array}{l}\mathrm{CP} \\
(\%)\end{array}$ & $\begin{array}{l}\mathrm{ASH} \\
(\%)\end{array}$ & $\begin{array}{l}\mathrm{EE} \\
(\%)\end{array}$ & $\begin{array}{l}\mathrm{CF} \\
(\%)\end{array}$ & $\begin{array}{l}\text { NFE } \\
(\%)\end{array}$ & $\begin{array}{l}\text { GE } \\
(\mathrm{kcal} / \mathrm{g})\end{array}$ & $\begin{array}{l}\text { TIA* } \\
(\mathrm{mg} / \mathrm{g})\end{array}$ & UA** $^{* *}$ \\
\hline Corn & 99.91 & 7.04 & 1.86 & 4.41 & 1.32 & 85.38 & 3.68 & \\
Corn Offal & 90.74 & 11.07 & 2.94 & 3.30 & 9.16 & 73.53 & 3.00 & & \\
Fish Meal & 93.45 & 61.18 & 2.74 & 19.34 & 0.85 & 15.89 & 3.35 & & \\
Extruded Full & & & & & & & & & \\
Fat Soyabean & 92.39 & 36.55 & 6.49 & 19.36 & 6.13 & 31.47 & 4.64 & 8.18 & 0.19 \\
Raw Soyabean & 92.18 & 31.33 & 5.61 & 18.54 & 5.98 & 38.54 & 4.64 & 19.60 & 2.03 \\
\hline
\end{tabular}

reduction in carcass weight at 6.6 and $13.4 \%$ levels of RSB inclusion in diets could be related to reduced body weight gain (Table 2) and poor feed utilization. The reduced LEA could be related to lowered availability of protein in the experimental diets resulting from trypsin inhibitor activity in RSB. Thus deliciency of one or more amino acids might have occured. Brown et al., (1974) reported that LEA increased as the level of lysine increased when adequate diets were fed to pigs. 13.4 and $23 \%$ RSB diets were deficient in dietary lysine in this study.

Based on the performance of animals fed RSB as the sole supplemental protein and the carcass quality exhibited by them, the use of raw soyabeans diet for finishing pigs is recommended. 


\section{TABLE 3: PERFORMANCE OF FINISHING PIGS FED RAW OR EXTRUDED FULL FAT SOYABEANS}

\begin{tabular}{lllllll}
\hline & 1 & 2 & DIETS & 3 & 4 & SEM \\
\hline Initial Weight (kg) & 49.75 & 50.26 & 50.00 & 50.00 & \\
Final Weight (kg) & 91.75 & 90.00 & 90.00 & 91.00 & \\
Av. Daily Feed intake (kg) & 2.68 & 2.14 & 2.70 & 2.23 & 0.30 \\
Av. Daily Gain (kg) & 0.83 & 0.62 & 0.74 & 0.82 & 0.12 \\
Feed Efficiency & 3.24 & 3.24 & 2.92 & 2.75 & 0.54 \\
\hline
\end{tabular}

\section{TABLE 4: CARCASS CHARACTERISTICS OF FINISHING PIGS FED RAW OR} EXTRUDED FULL-FAT SOYABEANS

\begin{tabular}{|c|c|c|c|c|c|}
\hline INGRIDIENT & 1 & 2 & $\begin{array}{l}\text { DIETS } \\
3 \\
\end{array}$ & 4 & SEM \\
\hline $\begin{array}{l}\text { Warm Dressing \% } \\
\text { Estimated Loin }\end{array}$ & 59.10 & 56.10 & 56.80 & 65.10 & 3.40 \\
\hline $\begin{array}{l}\text { Estimated Loin } \\
\text { Eye Area }\left(\mathrm{CM}^{2}\right)\end{array}$ & 31.45 & 26.20 & 23.10 & 28.35 & 3.90 \\
\hline \% Lean Cuts & $74.00^{b}$ & $75.8^{3}$ & $75.40^{3+b}$ & $73.30^{b}$ & $0.53^{*}$ \\
\hline \% Fat Cuts & $26.00^{\mathrm{a}}$ & $24.00^{b}$ & $24.50^{6}$ & $26.70^{*}$ & $2.30^{*}$ \\
\hline Backfat Thickness (CM) & $3.30^{\mathrm{ab}}$ & $2.10^{\mathrm{c}}$ & $4.00^{\mathrm{a}}$ & $3.80^{\mathrm{ab}}$ & $0.27^{\circ}$ \\
\hline Carcass Length (CM) & 73.00 & 69.00 & 67.50 & 73.80 & 2.65 \\
\hline
\end{tabular}

- Means without common superscrpts in horizontal rows are significantly different $(\dot{P}<0.05)$.

\section{REFERENCES}

A.A.C.C. (1969) Official Methods of Analysis. American Association of Cereal Chemists (AACC). WASHINGTON D.C.

A.O.A.C. (1984) Official Methods of Analysis (14th ed) Association of Official Analytical Chemists (AOAC) WASHINGTON D.C.

BROWN, N.W., B.G. HARMAN and A.L. JENSEN (1974). Total Suphur containing Amino Acids, Isoleucine and tryptophan requirements of the finishing pigs for maximum nitrogen retention.J. Anim. Sci. 38: 59-63.

COMBS, G.E. and H.D. WALLACE (1969). Raw and heated soyabeans for young, growing and finishing swine. Florida Agric. Exp. Sta. Annu; Grainesville.

COOKE, O.A. and J.R. FRALEY (1987). Response of young pigs to raw trypsin inhibitor Soyabeans as source of dietary protein. J. Anim. Sci., 05:1 (Abstr).

CRENSHAW, M.A. and D.M. Danielson (1985). Raw Soyabeans for growing-finishing pigs.J. Anim. Sci 60: 725 - 730.

DANIELSON, D.M. (1985). Raw Soyabeans in pig feeding. Pig news and Info, 6:35.

DUNCAN, D.B. (1955). Multiple range and multiple F-Test. Biometrics 11: 1-42
HANK, H.E., J.W. Rust, R.T. Meade and L.E. HANSON (1972). Influence of source of soyabeans protein and pelleting on the rate of gain and gain/feed of growing swine. J. Anim. Sci., 35: 958-961.

PONTIFF, J.E; L.L. Southern, D.F. Combs, K.W. Macmillian, T.D. Binder and K.K. Watkins (1987). Gain, Feed efficiency and Carcass quality of finishing swine fed raw soyabeans. J. Anim Sci., 7: 228-232.

STEEL, R.G. and J.A. TORRIE (1980). Principles and procedures of statistics. A Biometrical approach (2nd ed). McGraw Hill books Co. N.Y.

VANDERGRIFT, L.W; D.A. TANKSLEY and.S.A. SANDERSON (1983). Digestibility of nutrients in raw and heated soyabeans for pigs. J. Anim. Sci. 57: 1215-1216.

YEN, J.J., T. HYMOWITZ and A.H. JENSON (1974). Effects of Soyabeans and different trypsin inhibitor activities on performance of growing swine. J. Anim. Sci 38: 304 - 312. 